
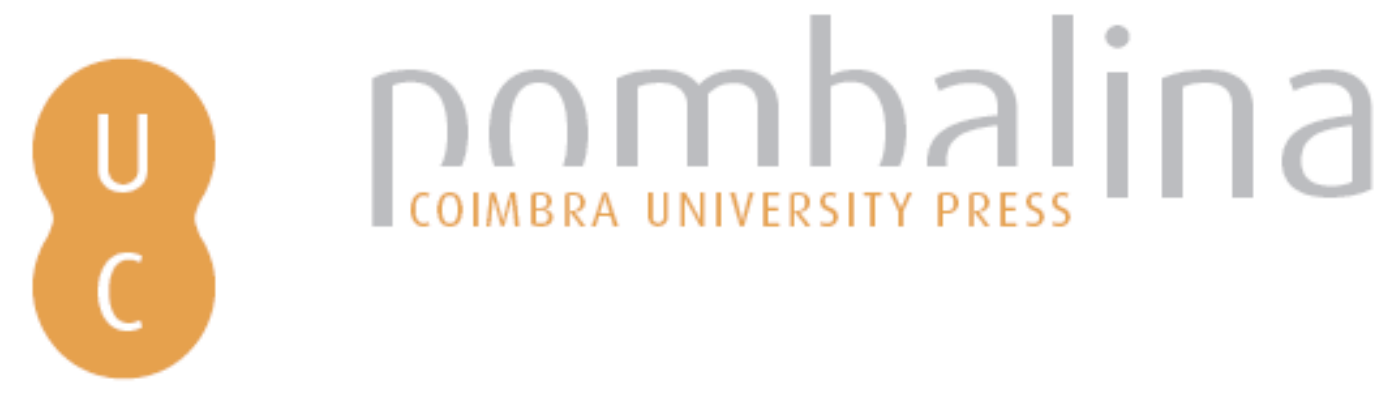

\title{
Studies for the asbestos exposure in Japanese urban population
}

\author{
Autor(es): $\quad$ Minami, T.; Ohtsu, N.; Yoshida, S.; Adachi, N.; Hishida, S.; Jamal, M.; \\ Tamaka, N.; Ghkubo, E.; Ameno, K.
}

Publicado por: $\quad \begin{aligned} & \text { Imprensa da Universidade de Coimbra; International Academy of Legal } \\ & \text { Medicine }\end{aligned}$

URL

persistente:

URI:http://hdl.handle.net/10316.2/31782

DOI:

DOI:http://dx.doi.org/10.14195/978-989-26-0173-1_29

Accessed : $\quad$ 26-Apr-2023 13:22:53

A navegação consulta e descarregamento dos títulos inseridos nas Bibliotecas Digitais UC Digitalis, UC Pombalina e UC Impactum, pressupõem a aceitação plena e sem reservas dos Termos e Condições de Uso destas Bibliotecas Digitais, disponíveis em https://digitalis.uc.pt/pt-pt/termos.

Conforme exposto nos referidos Termos e Condições de Uso, o descarregamento de títulos de acesso restrito requer uma licença válida de autorização devendo o utilizador aceder ao(s) documento(s) a partir de um endereço de IP da instituição detentora da supramencionada licença.

Ao utilizador é apenas permitido o descarregamento para uso pessoal, pelo que o emprego do(s) título(s) descarregado(s) para outro fim, designadamente comercial, carece de autorização do respetivo autor ou editor da obra.

Na medida em que todas as obras da UC Digitalis se encontram protegidas pelo Código do Direito de Autor e Direitos Conexos e demais legislação aplicável, toda a cópia, parcial ou total, deste documento, nos casos em que é legalmente admitida, deverá conter ou fazer-se acompanhar por este aviso.

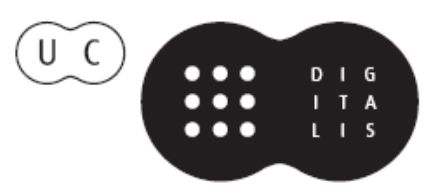




\section{Duarte Nuno Vieira Anthony Busuttil \\ Denis Cusack • Philip Beth}
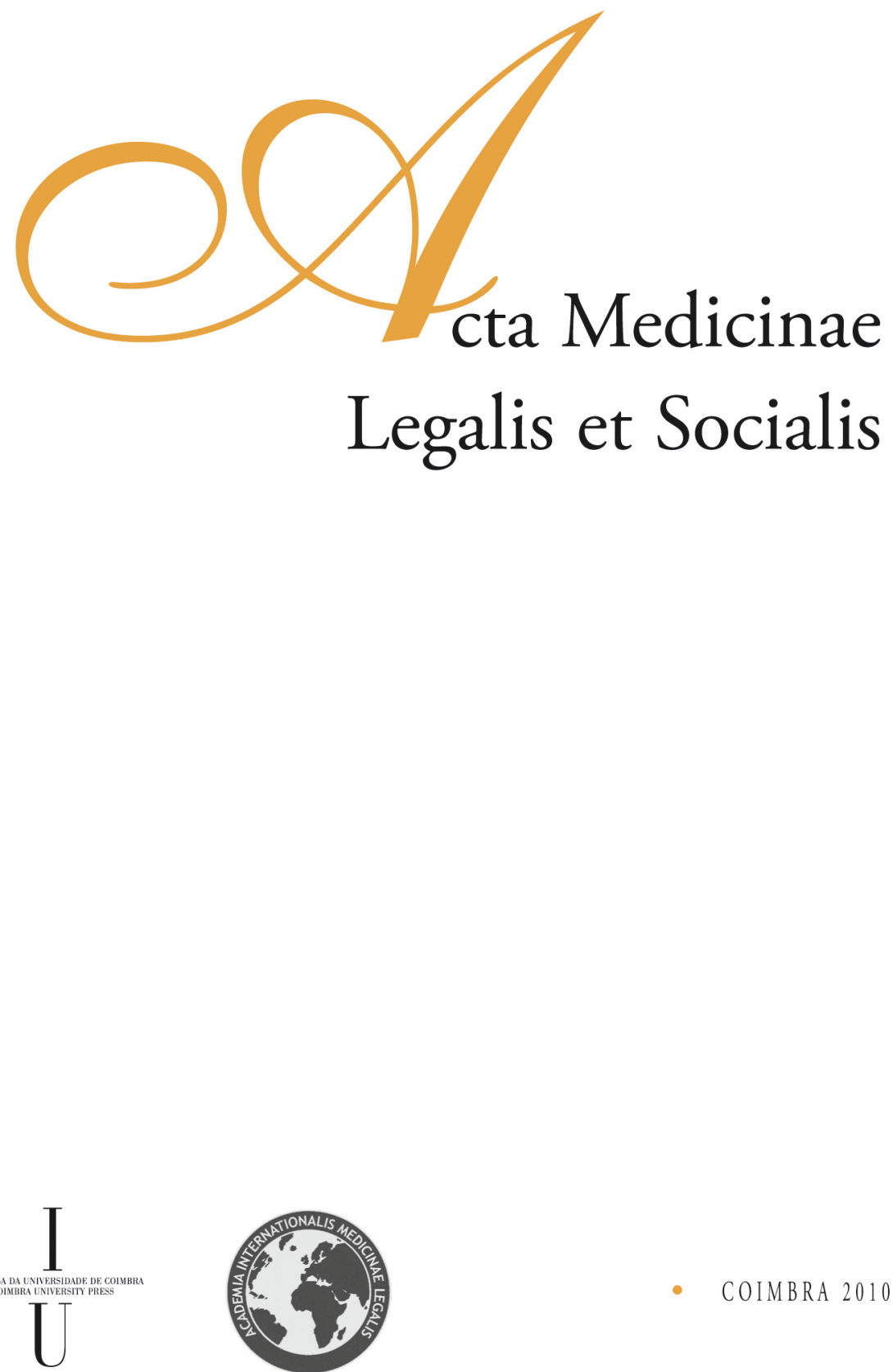
H. Kinoshita ${ }^{1}$, K. Matsui ${ }^{2}$, M. Takahashi ${ }^{2}$, M. Nishiguchi ${ }^{2}$, H. Ouchi ${ }^{2}$, T. Minami ${ }^{2}$, N. Ohtsu' ${ }^{2}$ S. Yoshida ${ }^{2}$, N. Adachi ${ }^{2}$, S. Hishida ${ }^{2}$, M. Jamal ${ }^{1}$, N. Tamaka, E. Ghkubo, K. Ameno ${ }^{1}$

${ }^{1}$ Department of Forensic Medicine, Kagawa University, Japan

${ }^{2}$ Department of Legal Medicine, Hyogo College of Medicine, Japan

\title{
STUDIES FOR THE ASBESTOS EXPOSURE IN JAPANESE URBAN POPULATION
}

\begin{abstract}
It has been well known that exposure of asbestos results in pulmonary diseases. Pulmonary concentration of asbestos bodies $(\mathrm{Ab})$ is a good indicator of asbestos exposure. The aim of the present study is to determine the pulmonary concentration of $\mathrm{Ab}$ in the Japanese urban population. We observed age dependent increase of incidence of Ab. This may indicate that the very low level exposure of asbestos would be continued in a daily life.
\end{abstract}

\section{Introduction}

Asbestos had been widely used as an industrial material, because of its physical properties such as heat-resistant, high tensile strength and flexibility (1). It has been well known that exposure of asbestos results in pulmonary diseases such as asbestosis, lung cancer and mesothelioma (1). Pulmonary concentration of asbestos bodies (Ab) is a good indicator of its exposure, and used for the assessment of the occupational exposure. It is widely recommended to identify persons with a high probability of exposure to asbestos dust at work over $1000 \mathrm{Ab} / \mathrm{g}$ of dry lung tissue (Helsinki criteria) (2). Only a few study have been reported Ab concentration in Japanese general population (37). The aim of the present study is to determine the pulmonary concentration of $\mathrm{Ab}$ in the Japanese urban population.

\section{Materials and Methods}

The lung tissue samples $(\mathrm{n}=530)$ were collected from the autopsy cases (above 10 years old) between 1974 and 1987 at the Department of Legal Medicine, Hyogo College of Medicine, Japan. The pulmonary concentration of Ab is determined by light microscopy, according to the method of Kohyama (8). In brief procedures are as follows; after small pieces of lung tissue (approximately $1 \mathrm{~g}$ of wet weights) was dried in air bath and weighted exactly, the samples were digested with laboratory breech (Clean99 K-200®, Clean chemical, Osaka, Japan) for few hours. The digested 
solutions were washed with distilled water, and adjusted the volume. A part of solution were filtrated through a membrane filter (pore size; $0.45 \mu \mathrm{m}$ ). The filter was fixed on a glass slide with acetone vapor and observed by light microscope. In the present study, we classified the pulmonary Ab concentrations, slightly modified the category of previous reports $(4,7)$.

This study was approved by ethical committee of Hyogo College of Medicine.

\section{Results and Discussion}

$\mathrm{Ab}$ are asbestos fibers that have been coated with ferroprotein by macrophages in the lung tissue (9), which is a good indicator of asbestos exposure. In the present study, we have investigated 530 autopsy cases. The 530 subjects are composed of 376 males (range: 10-85 year-old, mean: 44.9 year-old) and 154 females (range: 10-86 year-old, mean: 47.8 year-old).

Table 1 shows the incidence and distribution of the Ab concentration in lung samples. In 108 cases (20.4\%), we observed more than $100 \mathrm{Ab} / \mathrm{g}$ (male: 87 cases $(23.1 \%$ ), female: 21 cases $(13.6 \%)$ ). According to the Helsinki criteria, some of the investigated cases would be speculated as the occupational exposure, but not confirmed because of no detailed information of past occupational history. Figure 1 shows the incidence and distribution of the $\mathrm{Ab}$ concentration in each range of ages. We observed relatively high incidence of more than $100 \mathrm{Ab} / \mathrm{g}$ at the age of forties or above (forties; $26.8 \%$, fifties; $31.4 \%$, sixties; $32.4 \%$, seventies; $64.2 \%$ ) in males, and at the age of sixties or above (forties; $10.0 \%$, fifties; $9.1 \%$, sixties; $23.5 \%$, seventies; $33.3 \%$ ) in female. This data indicates that age dependent increase of incidence of the observation of more than $100 \mathrm{Ab} / \mathrm{g}$ lung tissue. This may also indicate that the very low level exposure of asbestos would be continued in a daily life. The observation of high incidence in the male is earlier and higher than that of female. This may be owing to the difference of the life style between male and female. In general, the work of the male in the open air is longer than that of female.

Figure 2 shows the distribution of the number of $\mathrm{Ab}$ in each year. The increase tendency of the exposure to asbestos may be observed year after year since late 1970 . In Japan, asbestos had been widely used until the prohibition of its use in October, 2004. The vast majority of asbestos used in Japan was imported, and it was peaked at the middle of 1970's (10). As the asbestos-related diseases have a long latent period, these diseases will continue to increase next 10-20 years. Further investigation would be required to clarify its relationship.

\section{Conclusion}

Our data indicate an age dependent increase of incidence of the Ab concentration (more than $100 \mathrm{Ab} / \mathrm{g}$ lung tissue). This may suggest that the very low level exposure to asbestos would be continued in a daily life. The increase tendency of the exposure to asbestos may be observed year after year. Further investigation would be required to clarify its relationship. 


\section{Aknowledgement}

This study has been partially supported by the grant from the Ministry of the Health, Labour and Walfare of Japan.

\section{References}

1) Craighead JE, Abraham JL, Churg A, Green FH, Kleinerman J, Pratt PC, Seemayer TA, Vallyathan V, Weill $\mathrm{H}$. The pathology of asbestos-associated diseases of the lung and pleural cavities: diagnositic criteria and proposed grading schema. Report of the Pneumoconiosis Committee of the College of Americam Pathologists and National Institute for Occupational Safety and Health. Arch Pathol Lab Med 106, 544-596, 1982.

2) Consensus report: Asbestos, asbestosis, and cancer: the Helsinki criteria for diagnosis and attribution. Scand J Work Environ Health, 23, 311-316, 1997.

3) Matsuda M. Studies on asbestos bodies. Jpn J Thoracic Dis 13, 40-44, 1975.

4) Murai $Y$, Kitagawa M. The incidence of pulmonary asbestos bodies in random autopsies in the hokuriku district. Jpn J Lung Cancer 24, 239-247, 1984.

5) Kobayashi H, Watanabe H, Zhang WM, Ohnishi Y. A quantitative and histological study on pulmonary effects of asbestos exposure in general autopsied lungs. Acta pathol Jpn 36, 1781-1791, 1986.

6) Honda K, Matsushita H, Hara M. Asbestos pollution in Tokyo -a comparative study on the lungs of autopsy cases in 1969 and 1985-. Jpn J Chest Dis 46, 1003-1008, 1987.

7) Tokuoka S, Tachiyama Y, Nambu S, Fujihara M, Yonehara S, Takeshima Y, Arihiro K, Kurihara K, Matsuura M, Kobuke T, Inai K. A study of secular trends in incidence and concentration of asbestos bodies in autopsied lung. Journal of Hiroshima Medical Association 42, 1398-1405, 1989.

8) Kohyama N, Suzuki Y. Analysis of asbestos fibers in lung parenchyma, pleural plaques, and mesothelioma tissues of north American insulation workers. Ann NY Acad Sci, 643, 27-52, 1991.

9) Churg AM, Warnock ML. Asbestos and other ferruginous bodies; their formation and clinical significance. Am J Pathol 102, 447-456, 1981.

10) Japan asbestos association. Import statistics. http://www.jaasc.or.jp/ 


\begin{tabular}{lrrrrr}
\hline & \multicolumn{5}{c}{ Concentration of Ab (per g dry lung weight) } \\
\cline { 2 - 6 } & $<100$ & $101-350$ & $351-500$ & $501-1000$ & 1000 \\
\hline Male $(\mathrm{n}=376)$ & 288 & 54 & 12 & 17 & 4 \\
\hline Female $(\mathrm{n}=154)$ & 136 & 10 & 6 & 4 & 1 \\
\hline
\end{tabular}

Table 1 - The incidence and the concentration of $\mathrm{Ab}$ in this study.

Figure 1(a)

Figure 1(b)
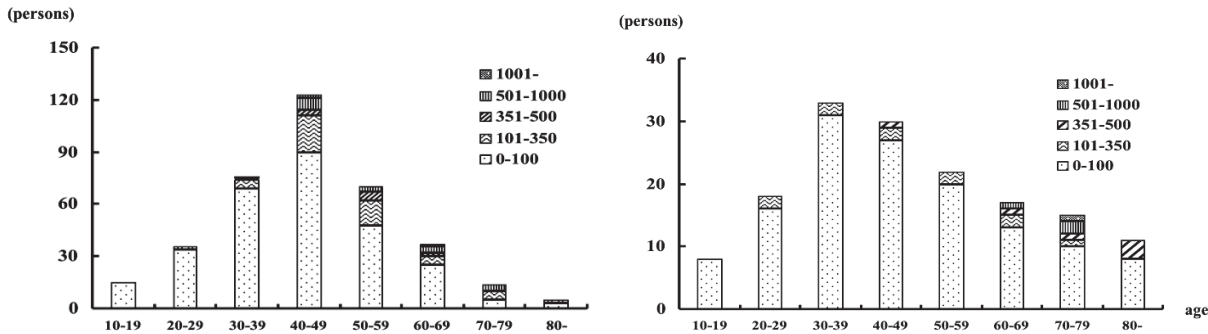

Figure 1 - The incidence and distribution of the $\mathrm{Ab}$ concentration (Ab/g lung tissue) in each range of ages of male (a) and female (b).

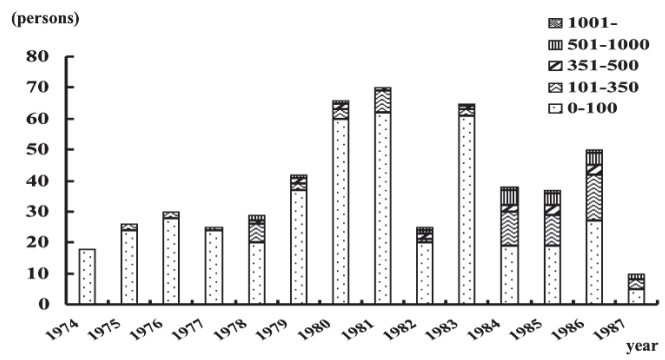

Figure 2 - The distribution of the number of $A b$ in each year. 